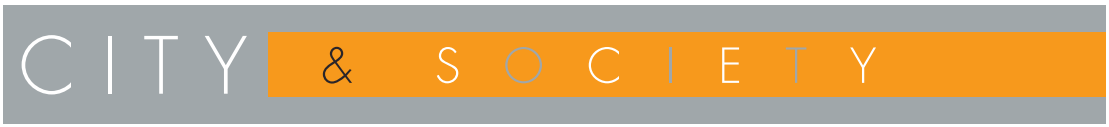

\title{
Kriolu Scenes in Lisbon: Where Migration Experiences and Housing Policy Meet
}

DEREK PARDUE

Aarhus University

\section{Abstract}

Since the early I990s, the Lisbon housing authorities have targeted "improvised" neighborhoods (e.g., poorly serviced neighborhoods with limited infrastructure) for removal or renewal into housing projects called "social" neighborhoods. Many of the neighborhoods undergoing transition are inhabited by Kriolu-speaking Portuguese of Cape Verdean descent. I analyze residents' responses to these changes, particularly the responses of young male rappers. My analysis reveals that rap music in these transforming neighborhoods is a means for making "Kriolu scenes" — expressions highlighting Cape Verdeans' experiences of Portuguese colonialism, postcolonialism, marginalization due to language and race, and now urban displacement. They are also expressions of belonging and cultural citizenship, and exercises of emplacement within the changing city. Kriolu scenes highlight an important but underappreciated role that language plays in shaping urban space. Methodologically, I draw from archival research, fieldwork in Lisbon neighborhoods, and interviews with local rappers of Cape Verdean descent. [Creole, Lisbon, Cape Verde, urbanization, space]

\section{Saturday evening in Lisbon:}

\section{A cultural mise en scène}

ए ar from the eletronica clubs, fado pubs, and other music scenes in the Bairro Alto designed to attract tourists is "Kova M," the Cape Verdean Creole name for Cova da Moura, one of the largest "improvised" housing settlements (i.e., a poorly serviced neighborhood with limited infrastructure) in the metro area. Although there are no clubs for tourists in Kova M, the scene is just as animated and hip. When I hiked through its hilly streets on a Saturday evening, I passed dozens of groups of kids, and I observed adults shouting, laughing, and calling after young men and women. I passed restaurants and open bars with live bands playing funaná music, ${ }^{\mathrm{I}}$ and I heard the sounds of charcoal bits crackling, punctuating the steady rhythms of Kriolu chatter around a street barbecue. Within the crowds on the streets I found the familiar faces of my friends LBC and Heidir, two local Kriolu rappers. I asked, "Hey, what's all the fuss, what's going on?" Heidir replied, "Normal, é festa, é Kriolu" (No big deal, it's a party, Kriolu). In unison the rappers said, " $\mathrm{N} u$ bai, é nhos, Kova M" (We are Kova M, c'mon). As we headed to the party, we walked past murals of Tupac Shakur and Bob Marley accompanied by stenciled images of police interrogation scenes with Kriolu captions (see 


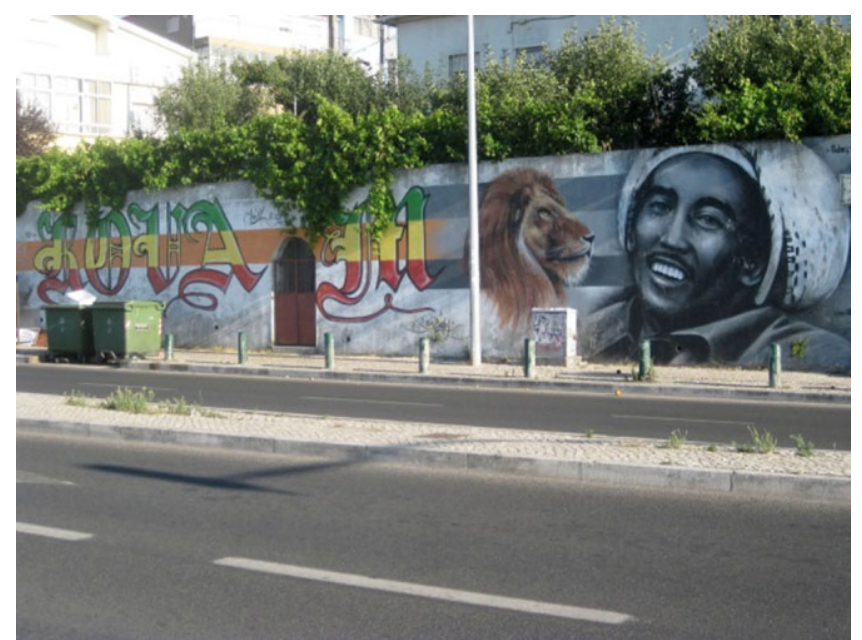

Figure I. Mural with "Kova M" calligraphy next to an image of Bob Marley. Photo by author, $201 \mathrm{I}$.

Figures I and 2). I wondered if this juxtaposition of local and global themes is a part of mural art in many global cities. Heidir and LBC screwed up their faces, and the sound of their Kriolu hailed me back to the reality in front of me-the concrete, alleyways, and barred windows of Kova M. Heidir and LBC cut short their screeds on police brutality for a moment and we stopped and took in the night as the lights from the sporadic street posts and passing cars flickered forming an outline at the base of the Kova M hill. Night had fallen and yet Lisbon's complex array of neighborhoods was becoming clearer. I began to realize the more I understood Kriolu not just as a language but as a spatio-temporal identity, the closer I would be to accessing the relationship between Portuguese public policy on peripheral housing and the cultural practices of its residents. The idea of place as a socio-political phenomenon was becoming clearer.

Kova $\mathrm{M}$ is one example of a Kriolu space where music and everyday talk are tactics for youth of Cape Verdean descent to claim legitimacy in Lisbon's peripheral cityscape. Kriolu consists of a mix of Portuguese vocabulary and syntactical structures of Niger-Congo languages, and it is an unofficial language in Portugal as well as in Cape Verde, an archipelago 350 miles west of Dakar, Senegal. Such an identity claim does not stem from a straightforward story of the development of ethnic enclaves or the marginalization of migrants in the city. Rather, it emerges from a vexed situation of belonging.

Cape Verdean Creole involves both mimesis and alterity. On the one hand, it involves an approximation to "Europe" facilitated by Portuguese colonial policies, late $20^{\text {th }}$ century citizenship laws, and cultural movements on the archipelago that mirrored intellectual trends in Portugal. On the other hand, "modern" Cape Verdeans express a close kinship with Brazil, a model of cultural hybridity and hence the perfect post-colonial nation-state. Unlike Libyans in Italy, Moroccans in France, or Sunni Muslims in England, who place themselves in suburban neighborhoods, 


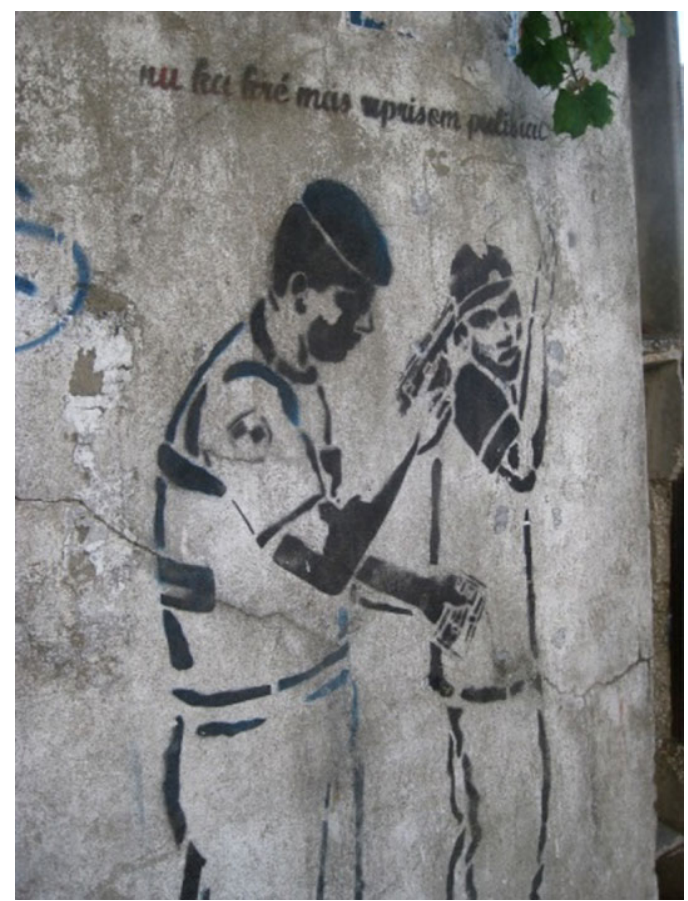

Figure 2. Stencil art of Kova M youth. Kriolu caption reads: "We don't want any more oppressive police." Photo by author, $20 \mathrm{I}$.

Cape Verdeans in Lisbon historically have not been viewed as "Other," but as a central part of "Lusotropicalism"- the Portuguese ideology that holds racial mixture as central to Portuguese identity both at home and abroad. Cape Verdeans distinguish themselves from other Luso-African émigrés in Europe by speaking Kriolu and using a creole identity to occupy intermediary roles of commerce, military actions, and political diplomacy (Batalha 2004; Chilcote i966). At the same time, Kriolu marks difference as Cape Verdean residents insist through a range of cultural practices that creole is not simply hybridity but its own generative force of specific identity formations. From this perspective, Kriolu and Lusotropicalism are assumed to be incompatible.

In this article, I relate Kriolu identity to emplacement within the rows of concrete block housing, refashioned alleyways, and streets of Lisbon's neighborhoods. In particular, I examine social interactions and cultural expressions related to a public housing project and an autoconstructed residential settlement. Kova M and Boba are two different kinds of neighborhoods in Lisbon with significant numbers of Cape Verdean residents who are confronting a public policy that aims to demolish all improvised housing and move residents into social housing. I show how Kriolu expressions and identity not only have symbolic value for residents, but remake the material realities of urban living. Evidence from Kova M and Boba reveal Kriolu identity is dynamic but ultimately limited in its political effectiveness to challenge certain urbanization projects. Public-private housing partnerships have been successful in creating new urban communities and in shaping Portuguese citizens. 
While new urban policies seek to improve housing options and the look of the city, they tend to reinforce a social hierarchy with Cape Verdeans, other Luso-Africans, and immigrants positioned low in the order and generally as an "Other." In response, Kriolu rappers and many Cape Verdean youth have become more vocal in their stance that new urban policies are muting cultural identities. Creating scenes by using Kriolu identity and language is the means by which people are "owning" the improvised housing and expressing anxiety about the possibility of being displaced once again.

My findings are based on archival research regarding Kriolu in the colonial period, particularly from the reorganization of cultural attitudes after the Berlin Conference of I 885 until the fall of the Salazar-Caetano dictatorship in $1974 . .^{2}$ and seven non-consecutive months of ethnographic fieldwork in Lisbon conducted between 2007 and 2013. Germane to this article, I visited Alto da Cova da Moura (Kova M) twelve times and Boba six times since 2007. Visits ranged from one to eight hours, depending on the day of the week and the time of day of the visit. In these neighborhoods I conducted a series of informal interviews with thirteen self-identified Kriolu rappers, ranging in age from twenty to thirty. In addition, I interviewed another twenty Cape Verdean residents, who are not rappers but are active in some capacity in their respective neighborhoods with regard to daycare, cultural centers, education, or public health. The majority of consultants were first-generation immigrants, born in Cape Verde, and migrated to Lisbon with one or more family members as a child. Ten of the thirty-three consultants were born in Lisbon and have Cape Verdean parents. Four were born in either the Azores or one of the former Portuguese colonies in Africa (e.g., Angola, Mozambique, Guinea-Bissau, and São Tomé e Príncipe). All but five consultants hold Portuguese citizenship officially, yet all self-identify as Cape Verdean or Kriolu.

\section{Scenes and neighborhoods}

A cademic research has explored the role of rap in relationship to various cultural phenomena such as youth, urban, and national identities, social movements, and as musical aesthetic. I join a small cadre of scholars who interpret rap as part of the transformation of urban space to place. ${ }^{3}$ In her oft-cited ethnography of hip hop culture, Tricia Rose ( 1994) explains the power of rap music as response to and reshaping the postindustrial city by black youth in the late I97os. More pertinent to creole emplacement, anthropologists Michel Laguerre ( I998) and Gina Sánchez Gibau (2005) have argued that Haitian and Cape Verdean diasporic communities in New York City and Boston, respectively, have forged identity through the materiality of the neighborhood exemplified by the corner store. For example, residents refer to the store as part of their community, and through language practices and visual art they infuse community identity into the concrete materiality of 
the locale. Thus, the corner store is more than a building, but a cultural place. In the same way, diasporic cultures can materialize and become part of the urban landscape.

A term used in popular culture and more recently employed by scholars that best characterizes the creative and competitive dimensions of locality is "scene" (Connell and Gibson 2003; Krims 2007; Straw I 99 I). Scholars of ethnomusicology have argued cogently that a "scene" "Scene" is a is a primary nexus point that connects aesthetics, sound in this case, with sociality, ethos and a deep sense of history (Krims 2007; Straw 2006). A primary nexus point that connects aesthetics scene also necessarily involves spatial differentiation, as in the grunge scene in Seattle, the hyphy scene in the Bay Area, or the grime scene in London. Of course, scenes, like any other category, are abstractions and thus are not comprehensive or deterministic. However, they can be heuristically useful in so far as they demonstrate a tendency or a source with sociality, ethos and a deep of social agency. For ethnomusicologist Frederick Moehn (2012), in his analysis of a musical shift in Rio de Janeiro, Brazil, the emergent scene revealed a nexus of alternative middle-class concerns during the sense of history neoliberal boom of the I99os, which revolved around being labeled as myopic folklorists or sell-out global imitators. I use the concept of a scene to understand the collective properties and spatial dimensions of Kriolu rap and its role in constituting Cape Verdean identification in a milieu of urban renewal.

The Kriolu rap scene in Lisbon is different from "Portuguese" rap (rap tuga) or Cape Verdean rap (rap kaubverdianu) as it depends on participants' belief and assertion that their identities are linked to inhabited space. Tuga and Cape Verdean rap, produced in Portugal and Cape Verde respectively, refer to specific geographic parameters. Kriolu rap, in contrast, has no obvious "home," and represents a claim for space inside an already delineated cultural territory. As a creole language and identity, Kriolu includes vocabularies and styles mediated by the encounter as well as differentiated through a diasporic pride.

The Kriolu scene uses the popular to draw attention and to facilitate its circulation in public presentations and information technology. Similar to the music scene in Austin, Texas during the I99os (Shank I994) or the hip hop scene in Newcastle, England (Bennett 2000), the Kriolu rap scene, and by extension Kriolu emplacement, in Lisbon relies less on commercial spaces of clubs and stores and more on the relative penetration into neighborhood community centers and the social ubiquity of streets. In this respect, Kriolu scenes contribute to the meaning of urbanization processes such as the transformation of improvised into social neighborhoods.

\section{European emplacement and citizenship}

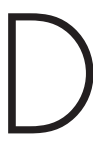
ue to the particular relationship between Portugal and Cape Verde, neighborhoods such as Kova M have become the sites of a unique form of emplacement. Here, emplacement refers to the heterogeneous routes of migrant displacement which produce unique 
cultural blends in emerging migrant settlements (Anderson and Lee 2005). It is clear from the ethnographic data in Lisbon that Kriolu emplacement occurs through different media and on varying scales. Kriolu is historical, discursive, and material, in addition to being transnational, diasporic and inter/intra-municipal.

The relationship between space and identification has been a frequent and productive topic of scholarship and public policy. In the European context, scholars have approached the issue of immigration and urban space in terms of collective action and socio-political agency (Bousetta 1997; Horta 2008; Sardinha 20ı; Suárez-Navaz 2004). In Portugal, as Horta explains, grassroots politics around space and identity is relatively new because terms such as multiculturalism, interculturality and ethnic minorities emerged only at the end of the twentieth century.

Scholars and government-sponsored agencies vary widely in their estimations of the actual number of Cape Verdeans residing in the Lisbon metro area. Anthropologist Luís Batalha (2008) notes that reports range between fifty and eighty thousand resident Cape Verdeans, depending on who conducts the research. Thousands of Cape Verdeans have achieved official Portuguese citizenship status, yet they self-identify as Cape Verdean. Most government surveys never count these people since they assume that if one has Portuguese citizenship, then one identifies as Portuguese (Batalha 2008; see Carling 2004).

While there have been significant populations of Cape Verdeans and other "black" Africans in Lisbon since at least the $15^{\text {th }}$ century, it is only since the I960s that "Luso-Africans" have become a more expressive demographic in the European capital city. Subsequently, starting in the early I990s, the Lisbon housing authorities have targeted improvised neighborhoods for removal or renewal into what is referred to as a "social neighborhood," 4 many of which contain a majority of Cape Verdean ethnic and Kriolu speaking residents.

Portugal's transition to a recognized multicultural nation-state and a labor importer is relatively recent (Cornelius I994). Two major periods of migration occurred in the 1960s, as the Salazar regime granted labor permits, especially to Cape Verdeans, to replace Portuguese nationals who had left for Angola and Mozambique in an effort to maintain Portugal's African colonies. In addition, Cape Verdeans were recruited inside Portugal to take the place of Portuguese emigrants who had departed to more highly industrialized nations such as France, Germany, and Luxembourg (Franco 1971; Rocha-Trindade 1979). This, coupled with a series of droughts on the islands along with a restrictive quota system for accepting Cape Verdean immigrants in the United States, helps explain the "boom" of Cape Verdeans in Portugal (Carreira I982). After 1986, when Portugal entered the European Union, a more diverse wave of migrants entered Lisbon with a strong Cape Verdean presence followed by Brazilians and, more recently, various East European and Asian nationals.

The expression of Kriolu as difference is not solely an organic development emergent from an isolated cultivation of a separatism on the part 
of migrant Cape Verdeans. By the i96os, a decade before the independence of the five Luso-African countries, as thousands of Cape Verdeans moved to Lisbon for employment in manual labor sectors of the economy, the Portuguese media in newspapers and television created a counter-narrative to the Cape Verdean as quasi-Portuguese (i.e., the ideal colonial subject). Using a mixture of folklore and on-site observation, journalists depicted Cape Verdeans as "good, strong workers" but easily angered and "hot-blooded." According to this logic, they caused danger in the workplace. Moreover, if left on their own, in the new, emerging periphery neighborhoods of Lisbon, they create dangerous residential areas (Batalha 2008).

While Cape Verdeans were an important source of labor in the colonial period, their status in Portugal was a different matter. For example, many Luso-Africans were subjected to the "Indigenous Code," which until r96r categorized Africans as either "indigenous" and thus too backwards and unproductive as laborers to qualify for full Portuguese citizenship or "assimilated" and thus included in the Portuguese polity. The assimilated status was viewed in Portugal as proof of the state's productive civilizing mission. As Meintel (2002) and others have argued, in reality the assimilated label did little to improve Cape Verdeans' opportunities and access to property, although it may have facilitated their access to higher education.

"Maybe Portugal

is in the EU,

but the PALOP

(African

\section{Countries with}

Portuguese as an

Official Language)

aren't. We're just

in Portugal

.. not quite

Portuguese, not

quite European

. . forever

African and

always black."

314

Such complex and often contradictory histories continue to influence socio-cultural perceptions in contemporary Lisbon. For example, ACIDI, the High Commission of Immigration and Intercultural Dialogue, the state agency that most comprehensively works with and researches immigrants inside Portugal, released a series of studies in 2006 regarding Portuguese interpretation of media. Through an analysis of mostly newspaper articles and television programs and commercials, the research team discovered that "Portuguese" viewers find it "difficult" to relate to "Africans" because they appear to be "less competent" and have less drive toward accomplishment than Brazilians, Eastern Europeans, and East Asians, respectively (See also Campos and Simões 2014). Anecdotally, I found such views commonplace across class, ethnicity and gender. Moreover, statistics concerning unemployment and formal education demonstrate a significant pattern of structural inequality among Luso-Africans in Portugal (Oliva 20ro; Santos, et al. 2012). It is thus unsurprising that many Luso-African youth residing in Lisbon continue to feel distant from fully recognized citizens. As one rapper summarized, "Maybe Portugal is in the EU, but the PALOP (African Countries with Portuguese as an Official Language) aren't. We're just in Portugal ... not quite Portuguese, not quite European ... forever African and always black."

That contemporary European citizenship involves tensions aroundinclusion and racial differentiation is, of course, not unique to Portugal. As Suárez-Navaz (2004) explains, the rapprochement of Spain with Europe in the I980s transformed what had been previously a general alliance along class lines between working-class Andalusians and African 
immigrants into a racialized difference marking the latter as a suspicious group of "foreigners" and "illegals" thereby constituting "Andalusia" as a "Mediterranean border" between "Europe" and "Africa" as well as between democratic modernity and dangerous traditionalism.

However, unlike the situation in southern Spain, actors invested in Kriolu negritude and local neighborhood politics have articulated the "naturalization of difference" (Suárez-Navaz 2004:7) as a form of public activism. This is despite the fact that xenophobic racism in Portugal carries significant heft in Portuguese politics, as represented in national parties of the right-wing populist CDS-PP and in social media venues such as Youtube and Facebook commentary. Whereas in Spain, Senegalese migrants employ the qualifier of "Muslim" to place themselves legitimately in Andalusia as part of regional histories and, indeed, "migrant" to take part in the "Andalusian collective memory" (Suárez-Navaz 2004: 8I), in Portugal, Cape Verdean youth purposefully mark themselves as Kriolu and thus not as part of Lusotropicalist history of hybridity and quasi-Portuguese status. They see themselves as transnational African residents who shape the present Lisbon.

\section{Moving towards "social neighborhoods"}

A main point of intersection between urbanization, labor, migration, and citizenship in Lisbon is the "social neighborhood," a standardized design, featuring clustered apartment buildings around a central plaza with accessible streets of commerce, which provide basic services of groceries, baked goods, café, popular restaurants, clothing, hardware, and household items. After the I88 I "Industrial Study" (Inquerito Industrial), a state evaluative report on national industries, city administrations began to consider more seriously the geography of labor. The challenge was how to manage urban space to maximize labor efficiency. State urbanization agencies responded in two ways: "pátios" and "vilas." The former refers to annexes and ad hoc construction for laborers behind the houses of elite urban property owners. Subsequently, real estate developers proposed to standardize the "patio" phenomenon and codify it as the "villa" thereby creating more spatial segmentation and differentiation (Pereira I994).

Social neighborhoods, first established in I9 8 , are essentially villas on a larger scale. After World War II, migrants from the countryside met significant groups of Cape Verdeans, and to a lesser extent Angolans and Mozambicans, and remade the Lisbon areas of Loures, Seixal, and Amadora into large residential municipalities with significant pockets of "improvised" settlements. In the I950s, Salazar began to address housing through a reinvestment in social neighborhoods to combat the surge of "clandestine neighborhoods" and informality outside of the municipality proper (Cardoso and Perista I994; Eaton I993). The implementation of subsequent laws around residential property exacerbated the stigma levied against those in auto-constructed communities. The stigma of
In Portugal, Cape

Verdean youth purposefully mark themselves as Kriolu and thus not as part of

Lusotropicalist history of hybridity and quasi-Portuguese status 
informality intensified after the implosion of the fascist regime and the concurrent independence movements in Lusophone Africa in I974 (Horta 200I).

Since r993, Lisbon's landscape of housing for the underemployed and working classes has gradually changed from a mixture of social and auto-constructed neighborhoods to almost exclusively social neighborhoods. With this said, it is important to underscore that the relationship between social and improvised housing in Lisbon is not Manichean with the former as a cold rigid drone village and the latter as an innovative cultural hub. Rapper Chullage, for example, has used the Lisbon municipality's official recognition of his social neighborhood, Arrentela, to gain funding and other resources so that he and his neighbors could transform the bottom floor of one of the housing project buildings into a hip hop cultural center and internet café. The center is called Khapaz, a purposeful misspelling of the Portuguese word capaz or "capable." In this case, cultural innovations are fostered within this social neighborhood. By the same token, improvised housing can result in alienation. For example, Gil, born in São Tomé e Príncipe of Cape Verdean parents, has lived in the improvised housing area of Santa Filomena (BSF), and has felt lost, defeated and sometimes not a part of any scene in Lisbon. He says:

When I was a kid, BSF was more alive. There were more people here, more community vibe. The thing is they don't just demolish our places in a day or so. No, it takes years. So, our BSF breaks up. Some people leave, some stay. You know, like divide and conquer. It's hard to live here now. Random people move in and out. There's no collective spirit anymore ... It's a struggle but, as a rapper, I try to bring a little BSF reality to the overall Kriolu thing going on in Amadora ...

The "they" in Gil's story refers to a coordinated team of state and commercial employees, whose goal is to appropriate the public land and develop it in a strategic manner in accordance with the demands of the market. But as Gil points out, the appropriation and fragmentation of the neighborhood "takes years." In 2009, roughly 50 percent of BSF had been demolished. By August 2013, 90 percent was gone. In this case, the flow of people in and out of the neighborhood exposed the neighborhood infrastructure to stigmatizing socio-economic activities such as illegal drug trafficking and prostitution. These activities sometimes resulted in violence and added greater stigma to the residential area. Gil contrasted this gradual, sometimes painful transition, with nostalgia of the early years of BSF. The bygone "community vibe," in fact, followed a much faster yet more distant inter-urban migration, predominantly from Praia and Tarrafal, in Cape Verde to Lisbon. Residents such as Gil relate the loss of cultural expression in the improvised housing setting to migrations within the city. But the memories of these migrations also strengthen BSF residents' identification with their neighborhood. Youth like Gil find Kriolu and the socio-linguistic practice of rap to be a potential vehicle for expressing these neighborhood changes as well as relationships between the neighborhood and a wider scene, the "overall Kriolu thing going on in Amadora." 


\section{Kriolu attempts at neighborhood formation}

7 he neighborhoods Kova $\mathrm{M}$ and Boba demonstrate a contrast in terms of the relationships between language, space, identity, and urban policy. While Kova M is (in)famous as Lisbon's largest improvised neighborhood predominantly comprised of residents of Cape Verdean descent, Boba is a smaller, more recently developed social neighborhood. Current urban renewal policies in Portugal privilege partnerships with private development corporations, and thereby are shaping Lisbon's periphery more in the mold of Boba, with pockets of isolated communities such as BSF, rather than a culturally rich and diverse mix of Kova M. Nevertheless, the language-identity of Kriolu remains one of the few effective idioms of resistance, or at least creative adaptation, in the face of living in Lisbon's residential projects. Despite the dreary reality of everyday life in Boba, speaking, rapping, and identifying as Kriolu contribute to an animated Kriolu scene which has permitted Boba to gain recognition and visibility that it otherwise would not receive.

Ghoya, a Kriolu rapper, who along with his rapping partner Boss, represent the problems of current relocation projects and the significance of Kriolu as a neighborhood signature. Ghoya moved to the social neighborhood of Casal da Boba in the municipality of Amadora in $200 \mathrm{I}$ when he was fifteen years old. He had previously lived in Benfica municipality in the improvised neighborhood of Fontaínhas. ${ }^{5}$ The demolition of Fontaínhas was part of PER (Special Program of Relocation), a project initiated in I993 sponsored by the Portuguese state and European Union agencies to eradicate the "tin can 'hoods" (bairro de lata) from Portugal's main cities of Lisbon and Oporto by the year 2000. Many of the residents from the Fontaínhas demolition ended up in Boba (note the reference to "Fontaínhas" in Figure 3). The main goal of

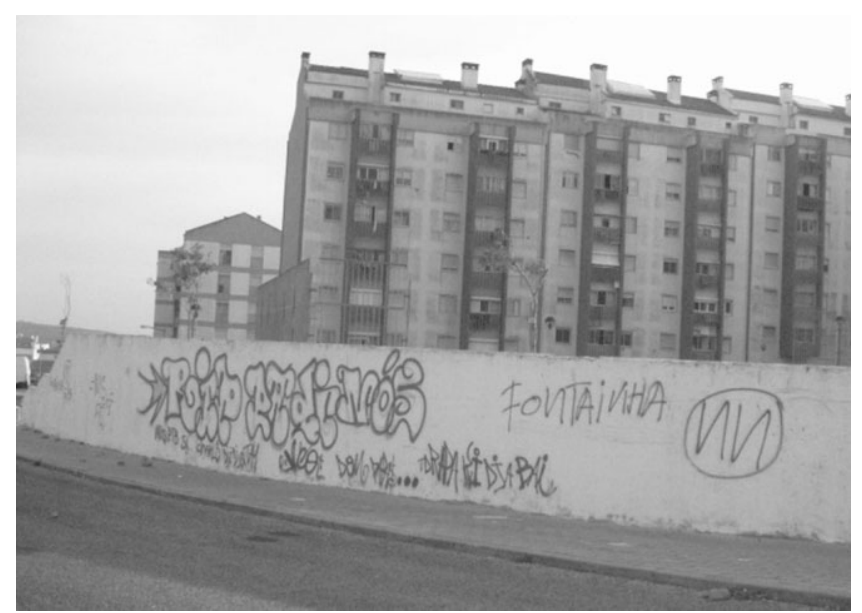

Figure 3. Neighborhood of Casal da Boba in background. Traffic barrier with "Fontainha" graffiti tag in the foreground referring to the demolished neighborhood of Fontaínhas. Photo by author, 2009 . 
PER is to efficiently relocate approximately I30,000 people living in unregulated, non-standard, poorly serviced communities to places with stable infrastructure.

In October of 2009 during our conversation in Boba, Ghoya described the relocation process after the demolition of Fontainhas in the following manner.

The experience here has been shit. You see these buildings? They're less than ten years old and you can see how they're crumbling. I mean, they didn't invest much in this. That's obvious. I'm old enough to remember Fontainha and that was tough, but we made that. People put that on the map ... The housing officials think that now it's all solved just because they made these white, cement boxes and call it new and then publish in the media that we are 'new'-meaning included folks. It's not true; there's no recognition. That's why you find young folks like me, Boss and dozens of others out here yelling and screaming. We're not interested in just asking for some help at the door; we're going to bust down the door so we can get some rights to make this place into our own.

According to Ghoya, the problem with Boba and the social neighborhood more generally is the assumed connection between spatial management (i.e., urbanization), and a collective sentiment about the city (i.e., urbanism). The idea that poor quality standardized housing represents inclusion into modern Portuguese society is a farce to Ghoya. What he found most distasteful, were untrue claims that the state and real estate contractors changed the migrant community, approximately sixty percent Cape Verdean in 2007, into "new" residents. Ghoya maintains that the social neighborhood has not addressed "spatial segmentation" or the "landscapes of inequality" (Suárez-Navaz 2004) embedded in neoliberal urbanization projects such as PER. The demolition of Fontaínhas and demographic transition of several hundred to Boba are facts of imposition. However, language at the stylistic level of rap lyrics and the ubiquitous level of public chatter became social practices which residents like Ghoya used to reconfigure Boba and thus "make this place into our own." Ghoya explains, "We start from the street. This is where we make ourselves. Ok, it looks different here in Boba than in Fontainha or wherever, but we make it work. That's one of the powers of Kriolu. We link Kriolu with rap to speak." The question is: how does Kriolu shape the "street," if at all? In my conversations Ghoya repeatedly employed "drama" to talk about the neighborhood. It wasn't until I heard several of his recordings and discussed these songs with Kriolu rappers around Lisbon that I was able to grasp a deeper sense of the operative imaginary. The Kriolu words for street and drama do not depart from those of Portuguese, "rua" and "drama," respectively. Consequently, it is not in the vocabulary, but in the narrative where Kriolu distinguishes itself as an emphatic and aesthetic practice, one that distinctively matches the sentiment of drama through linguistic flow to a new, engaging conception of the "street," "life," and other markers of the everyday. 
For example, in Ghoya's songs "Life is like that: today it's you, tomorrow it'll be me" and "The other side of the law," there is a frequent use of the first person objective case ("me") connected to the verb. This is a typical Kriolu verb-object construction that doesn't exist in Portuguese or in English for that matter. Ghoya places himself immediately in the songs as under stress or under an imposition: es kritikam or "they criticized me." Other examples include: "es dam" ("they gave me") and "es mandam" ("they told me or demanded from me"). The phoneme " $m$," when connected to the verb, changes the rhetorical stress from the conventional penultimate syllable "kritika" to the last syllable in "kritikam" thereby highlighting the morpheme of "me." Moreover, Ghoya and others often create emphasis, authority, and rhythmic tempo by using regularly "djam bai," a phrase ranging in meaning from "I'm outta here" or "I'm off" to "I'm going to do" something depending on subsequent text. The significance here beyond the " $\mathrm{m}$ " is the urgency and accentuation of "dja," the idea being that my actions will take place right now.

The aesthetic features of "kritikam" and "djam bai" are part of a Kriolu sound, and due to the success of rappers such as Ghoya, LBC, Chullage, and others, such sonorous qualities serve to reconstitute the "Lisbon sound" within popular music scenes (Connell and Gibson 2003:90-I 16; see also Märzhäuser 2010 regarding the adoption of some Kriolu vocabulary from Kriolu rap by non-Kriolu speakers in Lisbon). These rhetorical stress points give a punchy quality to the sound of Kriolu rap and enable the rapper to achieve the narrative goal of authority by way of a crisis (i.e., "something is happening to me").

Ghoya's unraveling of imposition is a drama often accompanied by sound mixes featuring synthesizers with sequences of high-pitched string instruments articulated in high reverberation. For Ghoya it is the "false nigga" and the "system" that work against him and by extension all his "people" of Boba and the "real" Kriolu rap scene. How is "reality" reconstituted? For Ghoya, sometimes it is not possible and his "feelings of rage and pain [related to police brutality, unemployment, jealousy] lead to prison, to the casket," but if it is to happen, a reconstructed reality emerges through the "sentiments of place." Ghoya raps "what we niggas have in common is suffering and solitude / recover that nigga in this place right now / the other side is a movement that hasn't fallen / these are our suburbs and streets / disillusion is enemy number one." Somewhat vague in his attempt to address suffering, Ghoya does locate it in a way that is both specific to the urban margins of Lisbon and also general enough to include anyone with sentiments of marginality. Based on fieldwork conversations with local rappers in Praia, Ghoya's stories have not only reached audiences back "home" in Cape Verde but in other diasporic locales of Rotterdam and Paris, thereby suggesting a transnational dimension to Ghoya's descriptions of his struggles in Boba and Lisbon more generally.

If Kriolu is a kind of "social imaginary" (Castoriadis 1987), a routinized medium of "worlding" or reality shaping (see also Narayan 2010),
Kriolu is a kind of "social imaginary," a routinized medium of "worlding" or reality shaping 
how do Boba residents translate the spoken language into an identifying landmark? While in Boba, use of Kriolu has yet to signal more than a tenor of difference marking residents who live in a neighborhood with a persisting stigma residents of Kova M use Kriolu to offer an alternative model of neighborhood space and identity.

\section{Kova M}

lto da Cova da Moura is a large improvised neighborhood in the
municipality of Amadora, located two miles south of Boba. Demo-
graphic information on Kova M's population varies significantly. While government numbers report six thousand people (ACIDI 2010) and independent sources cite ten thousand residents (Vaz 20I I), what is generally agreed upon is that, similar to Boba, Cape Verdeans make up roughly sixty percent of Kova $\mathrm{M}$. In contrast to Fontaínhas and Boba, Lisbon officials decided to spare Kova M from the PER demolition and urban renewal plan, in part due to local patronage (Horta 200 I). According to local mythology and community documentation, Kova M began with the end of Portuguese colonialism in $1974 .{ }^{6}$ For four years thereafter, a gradual but consistent stream of day laborers, consisting of predominantly Africans and the white Portuguese, who were forced to return to Portugal, the so-called retornados or "returnees," sought out residence close to the automobile accessory factory of Martins and Almeida and various construction sites, which contributed to the boom in social neighborhood urbanization, as discussed above. In I978, the municipality finally recognized Alto da Cova da Moura officially as a legitimate neighborhood, albeit improvised. Figure four shows a view from the entrance to Cova da Moura looking across the tracks to the social neighborhood of Damaia. Figure five depicts the main entrance to Kova $\mathrm{M}$ closest to the train station. Together, the images demonstrate a contrast in housing-the standardized project versus the improvised structures in Kova M.

Similar to Boba, Kova $\mathrm{M}$ youth are present in great numbers and want to link Kriolu talk and sound to neighborhood landmarks. This is

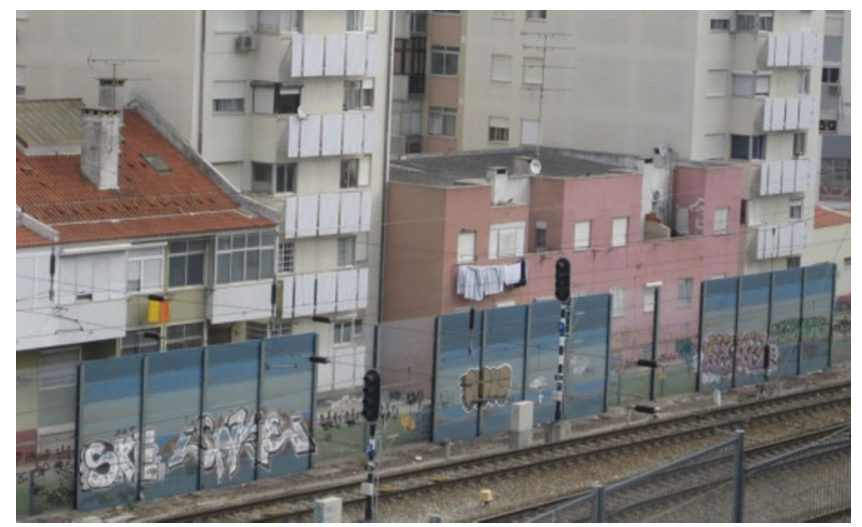

Figure 4. View from Cova da Moura of the planned, "social" neighborhood of Damaia on the other side of the train tracks. Photo by author, 2009 . 


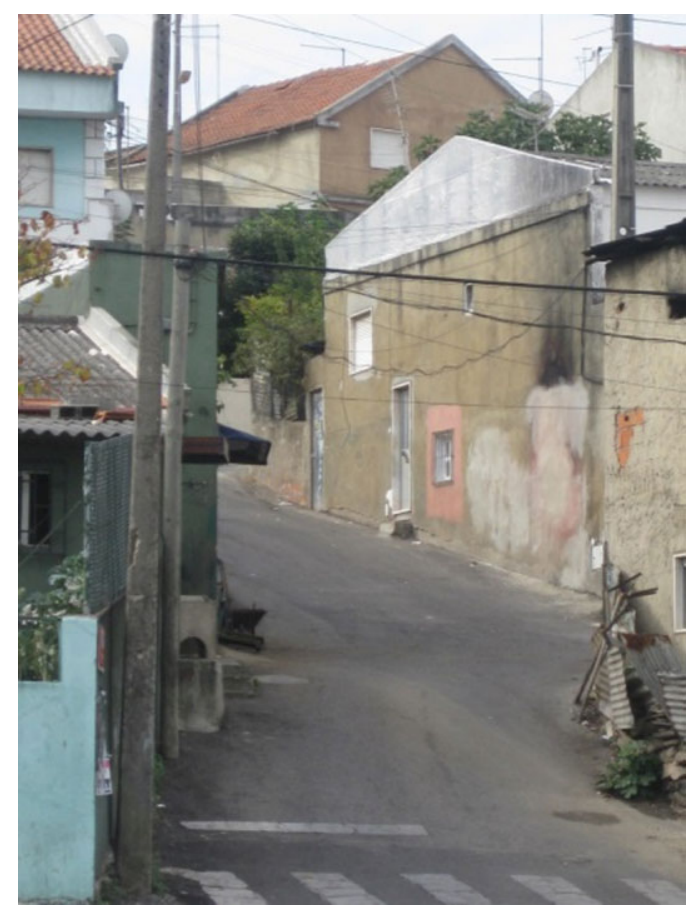

Figure 5. View of main paved entrance into the neighborhood of Cova da Moura, as seen from Damaia / Santa Cruz train station. Photo by author, 2009.

what they call making cenas or "scenes." I focus on two different types of "scenes." The first is represented by institutions such as Moinho da Juventude. The second "scene" recalls the introductory vignette of this article and highlights nighttime strolling and car cruising around the neighborhood.

In Portuguese, "moinho" means "mill," a traditional site of urban labor. However, another meaning associated with "moinho" is drawn from the colloquial phrase "to take the water to the mill"- to get the job done. Therefore, one might understand "Moinho da Juventude" as an organization focused on youth achievement. In fact, Moinho is a nonprofit organization that seeks to help residents of Kova M. have decent living conditions, healthcare, and childcare. In addition, it provides training and professionalization workshops. Moinho da Juventude began in 1984 as a grassroots project. It is now a formal organization that employees ninety-four people.

One day during my fieldwork, as kids ran by Moinho, which sits at the peak of this hillside neighborhood, Heidir, aspiring rapper, sound engineer, and veteran community activist, revealed his connection to the center. Heidir had been in prison for over two years for drug trafficking before we met in 2009. His brother was sentenced to five years. While in prison, they wrote pages of lyrics and soon after he returned to Kova M, Heidir spent as much time as possible in the Moinho's new recording studio. He saw it as a "platform to make a scene." We arrived at the recording studio, Heidir inserted his USB pen drive, cued up the control board, and made the desired adjustments for bass and volume. He signaled for me to sit beside him and soak up the sounds and lyrics. We 
listened to the seven-minute song about local corners and alleyways activated by police violence and residents' desperation. It was intense. Heidir never once looked at me. While he mouthed his lines and bobbed his head to the pounding downbeat of the bass drum, I stared at the lone microphone in the insulated recording room. I thought about amplification and platforms. Finally, Heidir spoke:

You see. That [the song] right there is drama. It is real experience. It is straight up Kova M. You know, outside of the neighborhood there are few options for us. Few people really move away because we end up finding something in our immediate surroundings that we connect with and make into something ... a living. For me and many others, it was drugs. But that is a dead end. Kova M has more scenes. That's a good thing. For me, rap and even more to the point, Kriolu rap is a good scene. There are two types of songs for me-drama and party. Drama, like the song I did with my brother right there, is real; it's about learning. It's fact. It's not about celebrating violence. It's just fact. Party is about celebrating Kova M; it's about pleasure and the spots ...

The landmark status of Kova M studio is well known. Many Lisbon-based Kriolu rappers record in Kova $\mathrm{M}$ and increasingly more "tuga" rappers are embracing Kova $\mathrm{M}$ as a respected point in the hip hop scene. In addition, directors of state cultural agencies such as Programas Escolhas, an organization that works with immigrant youth regarding issues of citizenship, education, and employment, have sponsored sound engineering workshops and rap contests linked to Kova M. ${ }^{7}$ So, the studio puts the neighborhood on the city's map. But as a site where youths' Kriolu identities are "milled" through rap, it inscribes Kriolu in the neighborhood while emplacing Kriolu youth within the city.

The colloquial reference of "Kova M" is interesting too because it illuminates how rappers such as Heidir and LBC purposefully inject Kriolu language politics into the spatial politics of scene-making. The letter "k" does not officially exist in the Portuguese language. It appears usually as a reference to English and by extension the global cache of the United States and "American culture." While certainly Kriolu rappers are influenced by US rappers' use of English, in this case, as well as with "Khapaz," the cultural center mentioned earlier in this article, the " $\mathrm{k}$ " refers to a difference from "tuga" and Portugal. It is not "crioulo;" it is Kriolu. It is not Cova da Moura but Kova M. Chullage explained the politics of Kriolu presence in this manner:

It's not just that I often feel more comfortable rapping in Kriolu, it's about getting everybody [non-Kriolu speakers in Portugal and rap fans around the world] to listen and go search for the meaning. It's what we all did when we first heard Public Enemy (the influential black nationalist rap group from Long Island, New York during the late i 980 and early I990s). We didn't understand English. We looked it up. People can do that with Kriolu. 
In sum, Kriolu rappers through orthography, pronunciation, and recording studio hype, have coupled language and space together and proposed it as a neighborhood value and an implicit obligation for others to learn or at least engage with Kriolu on its own terms.

Kriolu emplacement is not only a formal endeavor that can be traced back to a politically recognized community organization located in a specific site, and with members who manifest particular interactions and expressions. It also occurs in less formal settings and through the spontaneous gatherings of everyday life. To make this I point, I return to the vignette at the beginning of this article. My emerging friendships with Heidir and LBC garnered a series of weekend evening invitations. One particular Saturday night, I arrived in Kova M unannounced. I decided to climb the main road (see Figure 5) and not take my chances navigating the labyrinth of alleyways Heidir and LBC had shown me in prior visits. After the first fifty meters, I heard nothing but Kriolu. Kids of all ages, young adults and a few elderly folks were out in the streets. People were simply hanging out, sitting on steps, visiting friends, and making plans. Then I passed by the café owned by LBC's mom, Dona Anastácia. She told me to come in as a funaná band would shortly begin to play. Young men filled the tile-covered balcony. They were drinking sodas, beer, playing cards, and talking about soccer. Alyson, a twenty year-old rapper and recent immigrant from Santiago, impressed the men with his stories of life in Praia and the rough nature of living through droughts, dengue fever, and constant power outages. He battled rhetorically with the tales of money and labor from Simão, who was in town from Rotterdam, Holland, where he lived in a popular Cape Verdean community. The small crowd egged them on and eventually drowned out Alyson and Simão expressing, "Now, you all are here-the heart of Kriolu in Portugal. This is Kova M. Yeah!" As dozens of young men shouted "Kel li, Kova M," others added, in English, "Black lyrics, soldiers-soldiers, street, ghetto life." These expressions suggest, as previously mentioned, the juxtaposition of Kriolu and English in practice is less about the use of a stable entity called "English" or "Kriolu," but more about social practices of interest and persuasion. In this case, English and Kriolu are combined, reflecting experiences of blackness, masculinity, poverty, and violence, and the centrality of Kova $\mathrm{M}$ to its residents' identities. Observing this in the context of nightlife in the café reminded me that Kriolu scenes in Lisbon emerge from everyday interactions in ordinary spaces instead of landmark music studios or highly commercialized entertainment clubs, which tend to be the focus of many studies of rap music.

Later that evening, Heidir hailed me, LBC and Kromo, another Kova M rapper, over to his car and we took off. Kova M is not an easy place to drive, with its streets so narrow (see Figure five) that cars can barely get by all of the people who are seemingly always outside. Our cruising around curves, logistically going nowhere, was part of a game that included swerving, yelling out to everyone, and pumping a mix of Kova M studio Kriolu rap and the latest tunes by Lil' Wayne and 50 Cent. Heidir turned on the twelve-inch LCD screen and cued up a series of 
Jay-Z, 50 Cent, and Black Eyed Peas videos. Over the next hour or so, we made the rounds stopping at this and that corner, asking to talk with so-and-so, and inquiring about the whereabouts of so-and-so's sister. While Heidir exchanged extended greetings with Kova M residents, LBC joked but with serious undertones that we were outlining the youth boundaries of the neighborhood, the limiti di genti, in our excursion. From an informational standpoint, very little was exchanged in these conversations and inside the car the sheer volume of sound precluded much chitchat. When we arrived back in the area close to Dona Anastácia's café and the funaná music, Heidir turned around and asked, "So, D, did you feel Kova M?"

The joyride was meaningful on several levels. First, car travel is

Cars become

mobile stages for

individuals and

groups with

reputations to

amplify what

Heidir described

as "party" or

leisure life important in Kova M, especially for those of some means. Cars become mobile stages for individuals and groups with reputations to amplify what Heidir described as "party" or leisure life, as opposed to "drama" rap. Second, Heidir's question, "Did you feel Kova M?," was a provocation to consider the spatiality of the Kriolu keyword xinti, "to feel," the root of "sentiment." "Feeling" affords an understanding of youth leisure and everyday drama. In effect, the videos doubled as inside entertainment for the passengers as well as a complement to the interior and exterior lighting of the car. We glided by bumping and illuminating trails in the neighborhood-a party pod in the name of Kova M. Recalling the opening vignette, we had become one of those moving lights outlining a Kriolu space. Joyriding marked the city as well as made the Kova M, Kriolu vibe.

\section{Conclusion}

$\square$ ertainly, Kriolu is about being Cape Verdean, as for the past five hundred years Kriolu has echoed in public and privates spaces without any official recognition by the Portuguese colonial administration or, later, the independent Cape Verdean state. Yet, in the case of Ghoya, Heidir, LBC and others, Kriolu is not necessarily about the place of Cape Verde. Kriolu, as a symbolic system, affords a structured way of routinizing imagination, a "fantasy" (Weiss 2002) of community inside a society. Such imagination is more than mental fabrication, it is also aesthetic and material. Kriolu occupies space and becomes a scene by creatively provoking fellow Cape Verdeans, Luso-Africans and other Portuguese to recognize a Cape Verdean difference.

Local rappers' use of Kriolu in Lisbon exemplifies what Nicholas de Genova (2010) has described as the conflict between an "autonomy of migration" and state sovereignty. Cape Verde was born out of an early creole formation involving Portuguese sailors, West African traders, and displaced Muslims and Jews migrating out of Iberia. Movement is thus an essential part of Cape Verdean practices of language and identity. Recently, the Portuguese state and third-party real estate developers have provided another scenario in the long series of (dis)emplacement dramas 
for Cape Verdeans as Lisbon administrations have pushed to demolish improvised housing and regroup people into social neighborhoods.

While in the U.S. public opinion continues to reckon the project as a vertical slum, a negative residue of modern architecture, and an obsolete form of urbanization, in Lisbon, as is the case in many other parts of the world, the project or social neighborhood is a primary response to postcoloniality made manifest in migration demographics and the reorganization of labor. The case of Lisbon housing fits within the spectrum of reactions and policies based on a set of expectations by European states regarding labor migrants and urban space after the Second World War (Huttman, Saltman and Blauw r99i; Karakayali and Rigo 20ro). A convergence of increased labor demand in former European metropoles, increased political instability in African colonies, and persistent ethnocentric racism, in the case of Portugal cloaked in a national ideology of hierarchical multiculturalism (i.e., Lusotropicalism), occurred and helped create the political and market opportunity of social housing.

It is not the case that social housing is necessarily bad and improvised housing is pure positivity, rather that the gradual shift of the working poor to social neighborhoods in the Lisbon metro area has provoked many local youths to make more explicit their claims to place, not only because they try to combat stigma related to displacement, but because they strive to transform standardized urban planning into cultural identity. From this perspective, the Kriolu case supports the current scholarship regarding diaspora and place, which argues that migrants are significantly invested in being active "subjects" rather than simply "objects" (Anderson and Lee 2005:15). Moreover, the move to social housing has fortified the spirit of a cadre of activists to maintain improvised neighborhoods such as Kova $\mathrm{M}$ as distinct spaces. Cape Verdean Kriolu has emerged as one idiom with which youth work to reclaim control over their identification with space or what Brettell and Reed-Danahay describe as the "everyday practices of a cultural landscape" (201 2:38ff.).

The relationship between urbanization policies and urban experiences is a problem of agency, that life path of connecting self to recognized social structures. The Kriolu distinction within the milieu of immigration and housing in the New Europe is embedded in the historical contradictions of a relatively inclusive Portuguese colonialism with regard to Cape Verdeans and the differentiated linguistic practices of Cape Verdean creole. Kriolu rap in Boba is an outburst of conflict, a rage against the machine. In Kova M, rappers adopt this tone with respect to issues of employment, education, and immigration. However, they speak from more solid ground, and the socio-spatial achievements of Kova M facilitate a link between Kriolu and the pleasures of tourism, café life, daycare, and parades. In the words of Heidir, there are simply more "scenes."

The ethnographic cases of Kova M and Boba demonstrate that language and space are essential elements in identity formation because they mediate social history and citizenship politics, in this case, around the 
processes of migration, labor and race. ${ }^{8}$ Furthermore, the fact of territorial possession or leasing is not equal to the occupation of space. It is through occupation or emplacement that people invest value into space and are more or less recognized by the state as contributing to city or national culture. Presently, Kriolu scenes still do not resonate with the Portuguese state in any systematic way and thus reveal part of the discontent between migrants and the state in postcolonial Portugal.

While the case of Cape Verde emplacement in Lisbon is particular on many levels, an analytical focus on spatio-linguistic practices has potential for general application in the scholarship on migrant agency and cultural citizenship (Rosaldo I997). Accessible through anthropological fieldwork, the everyday practices of speaking, social interaction, and spatial occupation constitute one intersection between experience and policy. They are a basis of not only "community" (even a "scene") in an abstract sense of identity, but collectivity in the political sense of constituency. Case studies such as this one suggest new theoretical perspectives and methodological strategies to approach the global phenomenon of migration and identity.

\section{Notes}

Acknowledgements. I want to thank LBC, in particular, for his willingness to discuss Kriolu rap in Portugal. I also thank editor Suzanne Scheld and two anonymous reviewers for their thoughtful feedback. Of course, any shortcomings in the article are my own responsibility.

'Funaná is a Cape Verdean dance music typical of the island of Santiago that until independence was considered too "African" and "backward" for national identification. It is now one of the most popular genres of music both inside the archipelago and abroad

${ }^{2}$ Archives include the Library of the Lisbon Geographical Society (BSGL), Museum of the City, and the Overseas Historical Archives (AHU). In addition, since 2009 I have made two trips to Praia for a total stay of ten weeks.

3Throughout this text I use "space" and "place" somewhat interchangeably. In English and Portuguese, the connotations of "place" are rooted in a boundedness, a specificity, and seemingly closer to identity formation, while the meaning of "space" is generally more abstract, universal, and less articulated. However, as cultural geographers, such as Doreen Massey ( I 994) and Edward Soja ( I 996) following Henri Lefebvre (I99I), have pointed out, this dichotomy is a false one. "Place" necessarily includes more than the local just as "space" is always located "somewhere" vis-à-vis human practices. For either term to be salient in analysis, one must account for practices, e.g., language and labor, in a dynamic temporality.

"I use quotation marks around "social" and "improvised" as a reminder that these terms contain particular ideological connotations under debate in the context of contemporary Lisbon. 
${ }^{5}$ The official spelling is "Fontaínhas," but residents often referred to it as "Fontainha." Here, I maintained the difference as per the speaker's choice.

${ }^{6}$ According to Horta (2008:184-5), the history of Cova da Moura starts in 1940 with rural, white migrants in search of arable land.

7See the article in Fórum Escolhas, no. I2, July 2009:43-44.

${ }^{8} \mathrm{I}$ have limited my an analysis of the gendered dimensions of Kriolu subjectivity to a brief discussion of masculinity. Kriolu femininity is certainly significant and can be traced in such spatial practices as djunta mon (Weeks 2012). Also see Fikes (2009) for a compelling analysis of Kriolu femininity and social interactions in the marketplace.

\section{References Cited}

ACIDI (High Commission of Immigration and Intercultural Dialogue)

2006 Media, imigração e minorias étnicas II [Media, immigration, and ethnic minorities]. Lisbon: ACIME.

2010 Demographic Bulletin. http://www.acidi.gov.pt/banco-de-informacao, accessed on August, 20, 201 I.

Anderson, Wanni W. and Robert G. Lee

2005 Asian American Displacements. In Displacements and Diasporas: Asians in the Americas. Wanni W. Anderson and Robert G. Lee, eds. Pp.3-22. New Brunswick, NJ: Rutgers University Press.

Batalha, Luís

2004 The Cape Verdean Diaspora in Portugal: Colonial Subjects in a Postcolonial World. New York, NY: Lexington Books.

2008 Cape Verdeans in Portugal. In Transnational Archipelago: Perspectives on Cape Verdean Migration and Diaspora. Luis Batalha and Jorgen Carling, eds. Pp.6I-72. Amsterdam: Amsterdam University Press.

Bennett, Andy

2000 Popular Music and Youth Culture: Music, Identity and Place. London: MacMillan Press.

Bousetta, Hassan

1997 Citizenship and Political Participation in France and the Netherlands:

Reflections on Two Local Cases. New Community 23(2): 21 5-231.

Brettell, Caroline B. and Deborah Reed-Danahay

2012 Civic Engagements: The Citizenship Practices of Indian and Vietnamese Immigrants. Stanford, CA: Stanford University Press.

Campos, Ricardo and José Alberto Simões

20I4 Digital Participation at the Margins: Online Circuits of Rap Music by Portuguese Afro-descendantYouth. Young 22(I): 87-Io6.

Carling, Jorgen

2004 Emigration, Return and Development in Cape Verde: The Impact of Closing Borders. Population, Space and Place Io(2):I I3-I32.

Cardoso, Ana and Heloísa Perista

1994 A Cidade Esquecida: Pobreza em Bairros Degragados de Lisboa [The Forgotten City: Poverty in the Delapidated Neighborhoods of Lisbon]. Sociologia: Problemas e Práticas I 5:99-I I I.

Carreira, Antonio

I982 The People of the Cape Verde Islands: Exploitation and Emigration. London: C. Hurst and Co. 
Castoriadis, Cornelius

I987 The Imaginary Institution of Society. Cambridge, MA: MIT Press.

Chilcote, Ronald

I966 Developmental Nationalism and Lustropicology Concepts for Comparative

Study of Portuguese Africa? Paper given at Ninth Annual Meeting of the

African Studies Association, October 29.

Connell, John and Chris Gibson

2003 Sound Tracks: Popular Music, Identity, and Place. London: Routledge.

Cornelius, Wayne A.

1994 Spain: The Uneasy Transition from Labor Exporter to Labor Importer. In

Controlling Immigration: A Global Perspective. Wayne A. Cornelius, Philip

L. Martin and James F. Hollifield, ed. Pp.33I-370. Stanford, CA: Stanford University Press.

Eaton, Martin

I 993 Foreign Residents and Illegal Aliens: Os negros em Portugal. Ethnic and Racial Studies r6(3):536-562.

Fikes, Kesha

2009 Managing African Portugal: The Citizen-Migrant Distinction. Durham, NC:

Duke University Press.

Franco, Antonio Lusiano de Sousa

I97I A Emigração Portuguesa no Último Decénio: Causas Problemas e

Soluções [Portuguese Emigration during the last decade: Causes,

Problems and Solutions]. Guimarães, PT: Edição da Assembleia de

Guimarães.

Genova, Nicholas de

2010 The Deportation Regime: Sovereignty, Space and the Freedom of Move-

ment" In The Deportation Regime. Nicholas de Genova and Nathalie Peutz,

eds. Pp.33-65. Durham, NC: Duke University Press.

Gibau, Gina Sánchez

2005 Contested Identities: Race and Ethnicity in the Cape Verdean Diaspora. Identities I 2:405-438.

Horta, Anna Paula Beja

200 I Transnational Networks and the Local Politics of Migrant Grassroots Organizing in Postcolonial Portugal. ESRC Research Programme. University of Oxford, WPTC-02-03.

2008 A Construção da Alteridade: Nacionalidade, Políticas de Imigração e Acção Coletiva Migrante na Sociedade Portuguesa Pós-Colonial [The Construction of Alterity: Nationality, Immigration Policy and Collective Migrant Action in Post-colonial Portuguese Society]. Lisbon: Fundação Calouste Gulbenkian.

Huttman, Elizabeth, Juliet Saltman and Wim Blauw

I99 I Urban Housing Segregation of Minorities in Western Europe and the United States. Durham, NC: Duke University Press.

Karakayali, Serhat and Enrica Rigo

20I0 Mapping the European Space of Circulation. In The Deportation Regime.

Nicholas de Genova and Nathalie Peutz, eds. Pp.r23-144. Durham, NC:

Duke University Press.

Krims, Adam

2007 Music and Urban Geography. New York, NY: Routledge.

Laguerre, Michel S

I998 Diasporic Citizenship: Haitian Americans in Transnational America.

New York, NY: St. Martin's Press.

Lefebvre, Henri

I99I Critique of Everyday Life. Vol. I. London: Verso. 
Märzhäuser, Christina

20 Io Cape Verdean Creole in Lisbon-Young Generations' Perspective. TransInternet Journal for Cultural Studies, I $7 \mathrm{Nr}$. http://inst.at/trans/I $7 \mathrm{Nr} / \mathrm{I}-3 /$ I-3_maerzhaeuseri 7.htm, accessed July Io, 20I I.

Massey, Doreen I 994 Space, Place and Gender. Minneapolis, MN: University of Minnesota Press. Meintel, Deidre

2002 Cape Verdean Transnationalism,Old and New. Anthroplogica, XLIV: 25-42.

Moehn, Frederick

20 I 2 Contemporary Carioca: Technologies of Mixing in a Brazilian Music Scene. Durham, NC: Duke University Press.

Narayan, Kirin

2010 Placing Lives through Stories: Second-Generation South Asian Americans. In Everyday Life in South Asia. Diane P. Mines and Sarah Lamb, eds. Pp.472-485. Bloomington, IN: Indiana University Press.

Oliva, Anderson Ribeiro

2010. A história Africana no ensino superior Português (2002-2006) [African history in Portuguese secondary education]. Revista Cerrados 30: 93-106.

Pereira, Nuno Teutônio

1994 Pátios e Vilas de Lisboa, I870-I930: A Promoção Privada de Alojamento Operário [Patios and Villas in Lisbon, I870-1930: Private Development of Housing]. Análise Social 29( I 27):509-524.

Rocha-Trindade, Maria Beatriz

I979 Portugal. In International Labor Migration in Europe. R.E. Krane, ed. Pp. 164-I 72. New York, NY: Praeger.

Rosaldo, Renato

I997 Cultural Citizenship, Inequality, and Multiculturalism. In Latino Cultural Citizenship: Claiming Identity, Space, and Politics. William V. Flores and Rina Benmayor, eds. Pp.27-38. Boston, MA: Beacon Press.

Rose, Tricia

I994 Black Noise: Rap Music and Black Culture in Contemporary America. Middletown, CT.: Wesleyan University Press.

Santos, José Rebelo, Maria Filomena Mendes and Conceição Rego

2012 A imigração Africana em Portugal nos ultimos vinte anos: Oportunidades e ameaças no mercado de trabalho [African immigration in Portugal over the last twenty years: Opportunities and threats related to labor]. Actas do VII Congresso Português de Sociologia, Lisboa.

Sardinha, João

2010 Identity, Integration and Associations: Cape Verdeans in the Metropolitan Area of Lisbon. In Identity Processes and Dynamics in Multi-Ethnic Europe. Charles Westin, José Bastos, Janine Dahinden and Pedro Goís, eds. Pp.233-256. Amsterdam: Amsterdam University Press.

Shank, Barry

1994 Dissonant Identities: The Rock n' Roll Scene in Austin, Texas. Middletown, CT: Wesleyan University Press.

Soja, Edward W.

I996 Thirdspace: Journeys to Los Angeles and Other Real-and-Imagined Places. Cambridge, MA: Blackwell.

Straw, Will.

1991 Systems of Articulation, Logics of Change: Scenes and Communities in Popular Music. Cultural Studies 5(3):368-388. 
2006 Scenes and Sensibilities. E-Compós: Revista da Associação Nacional dos Programas de Pós-Graduação 6L: I-I6/. http://www.compos.org.br/seer/ index.php/e-compos/article/view/83/83, accessed August I5, 2014.

Suárez-Navaz, Liliana.

2004 Rebordering the Mediterranean: Boundaries and Citizenship in Southern Europe. New York, NY: Berghahn Books.

Vaz, Claúdia

20I I Tatuagens, graffitis e letras de rap: Formas de expressão e/ou rebeldia? Identidade de jovens da Cova da Moura [Tattoos, graffiti and gap lyrics: Forms of expression and/or rebellion? Youth identity in Cova da Moura Neighborhood]. Paper presented at Congresso Luso Afro Brasileiro de Ciências Sociais, August 9.

Weeks, Samuel

20I2 Marxian Crisis, Maussian Gift: The Mutual-Help Practices of Lisbon's Cape Verdean Labor Immigrants in an Age of Austerity. Theme issue, "Afro-Portugal," Cadernos de Estudos Africanos (24):27-43.

Weiss, Brad

2002 Thug Realism: Inhabiting Fantasy in Urban Tanzania. Cultural Anthropology I 7 ( I ):93-I 24 . 